\title{
PENGARUH KEPEMIMPINAN DAN MOTIVASI TERHADAP KOMITMEN ORGANISASIONAL SERTA DAMPAKNYA PADA KUALITAS LAYANAN (Studi Pada Rumah Sakit Referral Maubessi, Timor Leste)
}

\author{
Evelio Antonnio de Sousa \\ Fakultas Ekonomi dan Bisnis Universitas Udayana, Bali - Indonesia \\ email: sousaevelio@gmail.com
}

\begin{abstract}
ABSTRAK
Tujuan penilitian ini untuk mengetahui pengaruh kepemimpinan terhadap komitmen organisasional, pengaruh motivasi kerja terhadap komitmen organisasional, pengaruh komitmen organisasional terhadap kualitas layanan, pengaruh kepemimpinan terhadap kualitas layanan, dan pengaruh motivasi terhadap kualitas layanan. Hasil pengujian hipotesis (H1) membuktikan bahwa Kepemimpinan berpengaruh positif dan signifikan terhadap Komitmen organisasional memang terbukti benar. Berarti semakin baik kepemimpinan maka komitmen organisasional juga akan semakin baik. Hasil pengujian hipotesis (H2) membuktikan bahwa ada pengaruh motivasi terhadap komitmen organisasional terbukti benar. Semakin tinggi movitasi maka semakin tinggi juga komitmen organisasional. Hasil pengujian hipotesis (H3) membuktikan bahwa ada pengaruh signifikan dan positif komitmen organisasional terhadap kualitas layanan terbukti benar. Semakin baik Komitmen Organisasional, maka semakin baik juga kualitas layanan rumah sakit. Hasil pengujian hipotesis (H4) membuktikan bahwa ada pengaruh positif dan signifikan kepemimpinan terhadap kualitas layanan memang terbukti benar. Semakin baik Kepemimpinan, maka semakin baik juga kualitas layanan rumah sakit. Hasil pengujian hipotesis (H5) membuktikan bahwa ada pengaruh positif dan signifikan motivasi terhadap kualitas layanan memang terbukti benar, semakin baik motivasi, maka semakin baik juga kualitas layanan.
\end{abstract}

Kata Kunci : komitmen organisasional, motivasi kerja, kualitas layanan, kepemimpinan

\begin{abstract}
The purpose of this research is to determine the effect of leadership on organizational commitment, work motivation against the influence of organizational commitment, the influence of organizational commitment to quality of service, leadership influence on the quality of service, and the influence of motivation on the quality of service. The results of testing the hypothesis (H1) proves that leadership and significant positive effect on organizational commitment is proven true. Means the better the leadership, the organizational commitment will also be better. The results of testing the hypothesis (H2) prove that there is the influence of motivation on organizational commitment proved to be correct. The higher motivation the higher the organizational commitment. The results of testing the hypothesis (H3) prove that there is a positive effect of and organizational commitment to quality service is proved to be correct. The better the Organizational Commitment, then the better the quality of hospital services. The results of testing the hypothesis (H4) prove that there is a positive influence on the quality of leadership and service indeed proved true. The better the leadership, then the better the quality of hospital services.
\end{abstract}

Keywords : organizational commitment, work motivation, service quality, leadership 


\section{PENDAHULUAN}

\section{Latar Belakang}

Mengingat begitu khasnya tugas seorang tenaga kesehatan maka perlu memperhatikan berbagai aspek yang dapat mempengaruhi motivasi kerjanya sehingga dampak pada komitmen organisasinya menjadi positif. Seorang tenaga kesehatan mempunyai kontribusi yang tidak kalah pentingnya dalam usaha untuk mempercepat penyembuhan seorang pasien di rumah sakit. Berdasarkan latar belakang yang telah diuraikan, maka dibutuhkan investigasi tentang keberadaan semua tenaga kesehatan melalui Kepemimpinan dan Motivasi terhadap Komitmen Organisasional serta kualitas layanan. Hal ini disesuaikan dengan proses penyusunan rencana pembangunan Nasional Timor Leste yang memberikan peluang kepada seluruh rakyat Timor Leste dari anak - anak sekolah sampai orang tua, untuk memikirkan masa depan apa yang mereka inginkan bagi mereka sendiri dari generasi yang akan datang. Salah satu diantaranya adalah standar kesehatan, karena kesehatan di Timor Leste masih sangat rendah dan penyediaan fasilitas kesehatan belum memadai untuk meningkatkan kapasitas dalam bidang kesehatan ini sangat sulit dan fokusnya harus diarahkan kepada penyediaan layanan yang memenuhi kebutuhan - kebutuhan masyarakat.

Rencana pembangunan Nasional khusus pada bidang kesehatan lebih difokuskan pada kebutuhan - kebutuhan yang penting, dimana saat ini untuk meningkatkan kapasitas penyediaan layanan pendukung serta sistem manejemen untuk penyediaan program kesehatan di segala bidang, dengan maksud bagaimana 
melayani masyarakat yang membutuhkan pelayanan kesehatan. Untuk semua bidang yang dimaksud dalam peningkatan kapasitasnya pada tahun - tahun mendatang Timor Leste akan memerlukan dukungan Internasional untuk membantu bantuan dana pada program - program yang belum dapat dijangkau oleh pemerintah, tetapi pemerintah sendiri telah memberikan wewenangnya kepada Non Goverment Organization (NGO), (Internation Agency) untuk mengembangkan pelayanan kesehatan dasar (Primary Health Care).

Rencana pembangunan nasional khusus pada bidang kesehatan lebih difokuskan pada kebutuhan - kebutuhan yang penting, dimana saat ini untuk meningkatkan kapasitas penyediaan layanan pendukung serta sistem manejemen untuk penyediaan program kesehatan di segala bidang, dengan maksud bagaimana melayani masyarakat yang membutuhkan pelayanan medis untuk seluruh masyarakat Timor Leste.

\section{Rumusan Masalah dan Tujuan Penelitian}

Berdasarkan uraian latar belakang masalah dengan permasalahan tersebut, maka rumusan masalahnya yang menjadi perhatian dalam penelitian ini adalah sebagai berikut: (1). Bagaimana pengaruh kepemimpinan terhadap komitmen organisasional? (2). Bagaimana pengaruh motivasi terhadap komitmen organisasional? (3). Bagaimana pengaruh komitmen organisasional terhadap kualitas layanan? (4). Bagaimana pengaruh kepemimpinan terhadap kualitas layanan? (5). Bagaimana pengaruh motivasi terhadap kualitas layanan? 
Tujuan penelitian ini adalah sebagai berikut: (1). Mengetahui pengaruh kepemimpinan terhadap komitment organisasional di rumah sakit referral Maubessi. (2) Mengetahui pengaruh motivasi terhadap komitment organisasional rumah sakit referral Maubessi. (3) Mengetahui pengaruh komitmen organisasional terhadap kualitas layanan rumah sakit referral Maubessi. (4). Mengetahui pengaruh kepemimpinan terhadap kualitas layanan rumah sakit referral Maubessi. (5). Mengetahui pengaruh motivasi terhadap kualitas layanan rumah sakit referral Maubessi.

\section{KAJIAN PUSTAKA}

Menurut Kelly (2004), menyatakan kepemimpinan adalah proses ketika seseorang manajer mendorong bawahannya untuk berperilaku sesuai keinginannya, mengarahkan dan mengoordinasi kerja anggota kelompok, serta menghubungkan antara personal yang didalamnya setiap anggota patuh karena memang mereka ingin patuh, dan bukan karena mereka harus patuh dan kepemimpinan adalah suatu proses interaksi antara pemimpin dan karyawan dimana pemimpin berupaya untuk mempengaruhi karyawan untuk mencapai tujuan perusahaan atau organisasi (Nort house 2010; Yukl 2005).

Sedangkan Kotler dan Robbins (2010) berpendapat bahwa kepemimpinan berbeda dari manajemen. Manajemen berkaitan dengan hal - hal untuk mengatasi kerumitan. Manajemen yang baik dapat menghasilkan tata tertib dan konsistensi dengan menyusun rencana - rencana formal, dan merancang struktur organisasi 
yang ketat dan memantau hasil lewat perbandingan terhadap rencana yang telah ditetapkan sebelumnya. Motivasi kerja seorang pegawai biasanya ditunjukkan oleh aktivitas yang terus-menerus, dan berorientasikan tujuan. Jadi yang disebut pegawai yang bermotivasi adalah pegawai yang perilakunya diarahkan kepada tujuan organisasi dan aktivitas - aktivitasnya tidak mudah terganggu oleh gangguan - gangguan kecil (Gomes 2003). Adapun asas motivasi salah satunya adalah pemimpin mengajak karyawan untuk berpartisipasi dan memberikan kesempatan kepada mereka mengajukan pendapat dan rekomendasi dalam proses pengambilan keputusan. Dengan cara ini, bawahan merasa ikut bertanggung jawab atas tercapainya tujuan sehingga moral dan kerjanya akan meningkat (Hasibuan, 2009).

Komitmen organisasional adalah suatu keadaan dimana karyawan memihak kepada organisasi tertentu dan tujuan - tujuannya, serta berniat memilihara keanggotaannya dalam organisasi itu (Robbins 2006) sedangkan pendapat Husselid dan Day (Mc. Kenna dan Nich 2000) menyatakan bahwa komitmen organisasional dapat mengurangi keinginan untuk melepaskan dirinya dari organisasi dimana ya bekerja. Pandangan Porter et al. (2006), komitmen organisasi dan keterlibatannya dalam organisasi dicirikan oleh tiga faktor psikologis:

1) Keinginan yang kuat untuk tetap menjadi karyawan organisasi dimana ia bekerja.

2) Keinginan untuk bekerja keras demi organisasinya. 
3) Kepercayaan yang pasti dan penerimaan terhadap nilai-nilai dan tujuan organisasi.

Breet et al. (2009), yang menyatakan bahwa individu yang melakukan sebuah produktivitas kerja di bawah ekspektasi atasannya akan cenderung terlibat untuk melakukan perilaku yang kurang mendukung tujuan organisasi, karena mereka tidak melihat dirinya sendiri dapat mencapai tujuan yang diperlukan untuk bertahan dalam sebuah perusahaan melalui usahanya sendiri. Dengan demikian kualitas layanan karyawan akan meningkat, yang akan berdampak pada kualitas pelayanan karyawan. Sedangkan menurut Atep Adya Barata (2004: 21), pelayanan jasa yang diberikan oleh rumah sakit harus berkualitas dan memiliki lima dimensi kualitas yang utama yaitu: tangibles, reiability, responsiveness, assurance, dan empathy). Disadari ataupun tidak, penampilan (tangibles) dari rumah sakit merupakan poin pertama yang ditilik ketika pasien pertama kali mengetahui keberadaannya. Masalah kesesuain janji (reliability), pelayanan yang tepat (responsiveness), dan jaminan pelayanan (assurance) merupakan masalah yang sangat peka dan sering menimbulkan konflik.

\section{Hipotesis penelitian}

Program pengendalian kualitas pelayanan keperawatan di Rumah Sakit merupakan bagian penting dalam pelayanan keperawatan secara keseluruhan. Hal tersebut dapat tercapai dengan baik apabila salah satu peran kepala ruangan yaitu peran koordinasi dalam progam pengendalian kualitas layanan yang baik sehingga, berdampak baik terhadap kinerja perawat pelaksana dalam program 
pengendalian. Salah satu kegiatan pengendalian kualitas layanan keperawatan dapat dilakukan dengan kegiatan supervisi yang terutama dilakukan oleh kepala ruangan. Melalui kegiatan supervisi akan dapat diketahui apakah asuhan keperawatan kepada pasien dapat dijalankan dengan benar oleh perawat. Pelayanan rumah sakit yang menjadi perhatian dalam penelitian ini meliputi pelayanan medis, paramedis, dan penunjang medis. Pelayanan yang baik akan memberikan kepuasan kepada pelanggannya. Kepuasan dapat membentuk persepsi, dan hal ini dapat memposisikan produk perusahaan di mata pelanggannya. Pihak rumah sakit perlu mengetahui kualitas pelayanan yang telah diberikan, dan sampai seberapa jauh mempengaruhi kepuasan konsumennya. Hal tersebut penting sebagai acuan dalam pembenahan kualitas pelayanan, sehingga pelayanan yang diberikan bisa memberikan kepuasan pada tingkat yang optimal. Kualitas layanan merupakan inti kelangsungan hidup lembaga, artinya bahwa kelangsungan hidup sebuah lembaga sangat ditentukan oleh kualitas produknya. Para pelanggan akan mencari produk, berupa barang atau jasa dari perusahaan yang dapat memberikan pelayanan yang terbaik kepadanya (Assauri, 2006: 25).

Kotler (2010), mengatakan bahwa "Quality is the totality of features and characteristics of a product or service that bear on its ability to satisfy stated or implied needs." "Kualitas layanan adalah keseluruhan ciri serta sifat dari suatu produk atau pelayanan yang berpengaruh pada kemampuannya untuk memuaskan kebutuhan yang dinyatakan atau tersirat." Kualitas layanan tidak dapat dipisahkan dari produk dan jasa atau pelayanan. Groetsh dan Davis C. (Tjiptono, 2005:51) 
mengemukakan bahwa Kualitas layanan merupakan suatu kondisi dinamis yang berhubungan dengan produk, jasa, proses, dan lingkungan yang memenuhi atau melebihi harapan. Sampara (2009), mengemukakan bahwa Kualitas pelayanan adalah pelayanan yang diberikan kepada pelanggan sesuai dengan standar pelayanan yang telah dibakukan sebagai pedoman dalam memberikan layanan. Standar pelayanan adalah ukuran yang telah ditentukan sebagai suatu pembakuan pelayanan yang baik. Sedangkan menurut, Sinambela, dkk. (2006: 13) Kualitas adalah segala sesuatu yang mampu memenuhi keinginan atau kebutuhan pelanggan (meeting the needs of customers). Sedangkan menurut Goetsch dan Davis, kualitas layanan adalah merupakan kondisi dinamis yang berhubungan dengan produk, jasa, manusia, proses dan lingkungan yang memenuhi atau melebihi harapan. Berdasarkan kajian konsep dan hasil-hasil penelitian sebelumnya yang telah diuraikan di atas maka dapat dirumuskan hipotesis penelitian ini sebagai serikut:

1).Kepemimpinan berpengaruh positif dan segnifikan terhadap komitmen organisasional

2). Motivasi Berpengaruh positif dan segnifikan terhadap Komitmen organisasional

3). Komitmen Berpengaruh positif dan segnifikan terhadap kualitas layanan

4). Kepemimpinan berpengaruh positif dan segnifikan terhadap kualitas layanan 5). Motivasi berpengaruh positif dan segnifikan terhadap kualitas layanan 


\section{METODE PENELITIAN}

Penelitian dilakukan di Rumah Sakit Refferal Maubessi Kabupaten Ainaro dengan pengambilan data melalui penbangian qesioner. Penelitian ini juga merupakan penelitian kausalitas dimana terdapat hubungan antara dua variable atau lebih. Hubungan dalam penelitian ini merupakan hubungan kausal yaitu sebab akibat, dimana ada variabel exogen (bebas) yaitu variabel yang mempengaruhi dan variabel endogen (terikat) yaitu variable yang dipengaruhi.

\section{Variabel Penelitian, definisi operasional dan Pengukurannya}

Variabel dalam penelitian ini diidentifikasi sebagai variabel dependen dan variabel independen. Variabel dependen adalah adalah: Kepemimpinan (X1) dan Motivasi (X2). Variabel perantara dalam penelitian ini adalah Komitmen Organisasional (Y1). Sedangkan variabel tergantung/terikat mempunyai anak panah yang menuju kearahnya, yang dijadikan variabel tergantung/terikat adalah kualitas layanan (Y2).

\section{Populasi, Sampel dan Metode Penentuan Sampel}

Populasi dalam penelitian ini adalah pegawai yang bekerja di Rumah sakit Refferal Maubessi yang berjumlah 79 yang terdiri dari medis, paramedis dan pegawai non medis (administrasi). Prosedur penentuan sampel yang digunakan dalam penelitian ini adalah metode sesnsus yaitu pengambilan sampel dimana semua anggota populasinya di teliti dengan jumlah tenaga kesehatan yang ada di rumah sakit tersebut.

\section{Data dan Jenis Data}


Berdasarkan sumbernya, data dalam penelitian ini terdiri atas:

1). Data primer, yaitu data yang diperoleh secara langsung dari lokasi penelitian, baik dengan melakukan wawancara atau menyebarkan kesioner. Data primer dalam penelitian ini diperoleh melalui penyebaran kesioner kepada responden yang telah sesuai dengan kriteria yang ditetapkan.

2). Data sekunder, yaitu data yang diperoleh dan dihimpun oleh pihak lain dan perlu diolah kembali. Data sekunder dalam penelitian ini antara lain jumlah pegawai negeri yang bekerja di Rumah sakit Refferal Maubessi

\section{Metode Analisis Data}

Teknik analisis data yang digunakan dalam penelitian ini adalah model Path analysis. Model ini menganalisis pola hubungan antara variabel dengan tujuan untuk mengetahui pengaruh langsung maupun tidak langsung seperangkat variabel bebas (eksogen) terhadap variabel (endogen). (Ridwan dan Kuncoro 2008)

Persamaan dalam Analisis Jalur yang dipergunakan:

Sub Struktur 1: X3 = $\beta 1 \mathrm{X} 1+\beta 1 \mathrm{X} 2+\mathrm{e} 1$

Sub Struktur 2: Y1 $=\beta 3 \mathrm{X} 1+\mathrm{B} 4 \mathrm{X} 2+\beta 5 \mathrm{X} 3+\mathrm{e} 2$

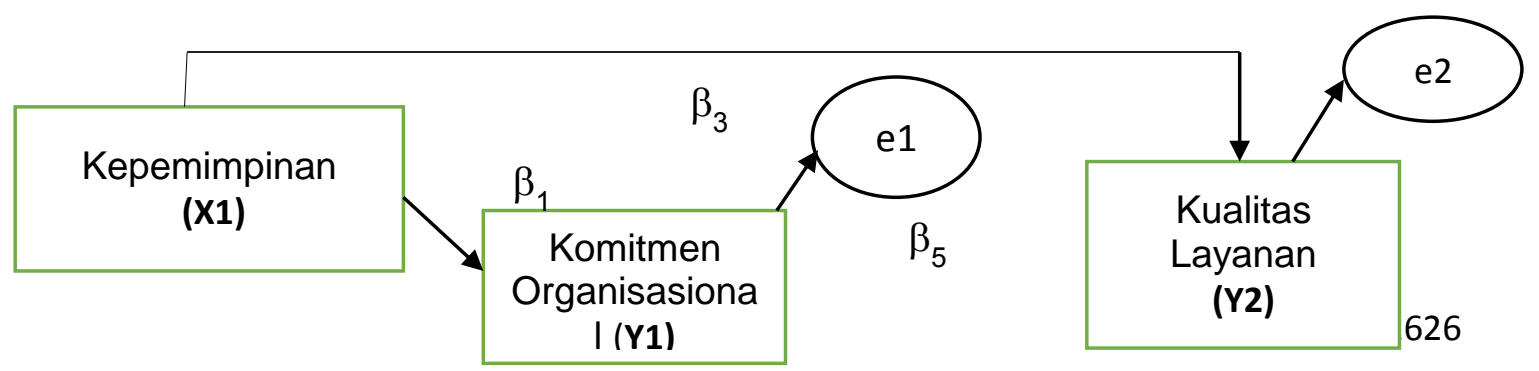




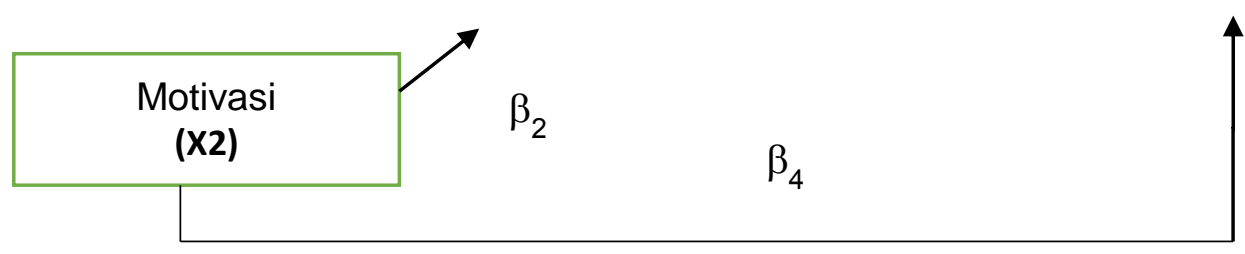

\section{Gambar 1. \\ Model struktural}

\section{Metode Pengumpulan Data}

Metode pengumpulan data yang digunakan dalam penelitian ini yaitu: metode observasi, yaitu: 1) observasi non perilaku yang digunakan untuk mengumpulkan data sekunder dari beberapa sumber. 2) Metode wawancara, yaitu wawancara dengan pimpinan perusahaan dan karyawan menggunakan daftar pertanyaan yang telah dipersiapkan sebelumnya. Wawancara mendalam (indepth interview), digunakan untuk memperoleh data primer dari beberapa perusahaan sampel; 3) Metode kuesioner, yaitu pengumpulan data dengan menggunakan instrumen penelitian (kuesioner) yang telah dipersiapkan sebelumnya. Instrumen penelitian ini digunakan untuk mengumpulkan data primer.

\section{Instrumen Penelitian}

Penelitian ini merupakan penelitian survey sehingga digunakan alat pengumpulan data berupa instrumen penelitian. Instrumen, sebelum digunakan untuk mengumpulkan data, terlebih dahulu diuji validitas dan reliabilitasnya.

Hasil uji validitas menunjukkan bahwa instrumen penelitian adalah valid. Hal tersebut ditunjukkan dari koefisien korelasi dari seluruh butir pertanyaan memiliki nilai $r>0,30$. Hasil uji reliabilitas juga menunjukkan bahwa empat variabel 
penelitian mempunyai reliabilitas yang dapat diterima, melihat semua nilai Alpha Cronbach di atas $0.60(\alpha>0,60)$. Dengan demikian instrumen penelitian ini bersifat reliabel.

\section{Teknik analisis data}

Penelitian ini menggunakan pendekatan analisis kuantitatif dan didukung dengan analisis kualitatif. Analisis kuantitatif menggunakan statistik deskriptif, dan regresi linear berganda.

\section{HASIL DAN PEMBAHASAN}

Hasil pengujian hipotesis (H1) membuktikan bahwa Kepemimpinan berpengaruh positif dan signifikan terhadap Komitmen organisasional memang terbukti benar. Berarti semakin baik kepemimpinan maka komitmen organisasional juga akan semakin baik.

Hasil penelitian ini mendukung penelitian terdahulu yang membuktikan bahwa kepemimpinan berperan besar dalam komitmen organisasional di mana sasaran atau tujuan yang ingin dicapai adalah berupa kualitas layanan di suatu organisasi yang maksimal. Reksohardiprojo (2007) juga membuktikan bahwa kepemimpinan mempengaruhi banyak factor, salah satuya adalah kualitas layanan organisasional. Hasil penelitian ini pula dilakukan oleh May-Chiun Lo et al. (2009) yang menyatakan kepemimpinan berpengaruh positif terhadap komitmen organisasi. Hasil pengujian hipotesis (H2) membuktikan bahwa ada pengaruh motivasi terhadap komitmen organisasional terbukti benar. Semakin tinggi 
movitasi maka semakin tinggi juga komitmen organisasional. Radiani (2009) berpendapat motivasi untuk melaksanakan pekerjaan di layanan jasa akan berpengaruh signifikan pada komitmen organisasional. Hal ini sejalan dengan

Daft (2003) juga membuktikan bahwa komitmen organisasi berpengaruh positif dan segnifikan terhadap komitmen organisasional di suatu organisasi layanan jasa. Hasil pengujian hipotesis (H3) membuktikan bahwa ada pengaruh seknifikan dan positif komitmen organisasional terhadap kualitas layanan terbukti benar. Semakin baik Komitmen Organisasional, maka semakin baik juga kualitas layanan rumah sakit. Hasil pengujian hipotesis (H4) membuktikan bahwa ada pengaruh positif dan segnifikan kepemimpinan terhadap kualitas layanan memang terbukti benar. Semakin baik Kepemimpinan, maka semakin baik juga kualitas layanan rumah sakit. Kepemimpinan berpengaruh positif dan segnifikan terhadap kualitas layanan perawat di Rumah sakit. Hal ini sependapat dengan (Cholil, 2003) kepemimpinan berpengaruh positif terhadap kualitas layanan karyawan di organisasi pelayanan jasa.

Hasil pengujian hipotesis (H5) membuktikan bahwa ada pengaruh positif dan segnifikan motivasi terhadap kualitas layanan memang terbukti benar, semakin baik motivasi, maka semakin baik juga kualitas layanan. Armanu (2004), dan Thoyib (2005) juga membuktikan bahwa Motivation berpengaruh positif terhadap services of quality dan memdapatkan justification dukungan secara impirik sehingga hasil penelitian ini diaplikasikan pada persoalan - persoalan yang sama. 


\section{Pengujian Hipotesis}

Berdasarkan hasil analisis regresi diperoleh bahwa kepemimpinan dalam pelayanan di rumah sakit referral maubessi, berpengaruh signifikan terhadap kualitas Layanan karena nilai signifikansi uji t sebesar 0,000 dengan koefisen jalur sebeasr 0,331 Hal ini berarti pengaruh langsung kepemimpinan pada kualitas layanan di Rumah Sakit referral maubessi. Demikian pula halnya dengan Motivasi berpengaruh secara signifikan terhadap Kualitas layanan dengan koefisien jalur sebesasr 0,273 dengan signifikansi uji t sebesar 0,002 . Hal ini berarti pengaruh langsung Motivasi terhadap kualitas layanan

Variabel Organizational Commitment juga berpengaruh signifikan terhadap kualitas layanan. Hal ini ditunjukkan oleh signifikansi uji t sebesar 0,000 dengan koefisien jalur sebesar 0,382.

\section{Pembahasan Hasil Penelitian}

Hasil pengolahan menunjukkan bahwa hipotesis pertama $\left(\mathrm{H}_{1}\right)$ memperoleh dukungan, hal ini ditunjukkan oleh nilai yang signifikan pada $\mathrm{p}<0,05$. Hal ini berarti bahwa Kepemimpinan berpengaruh positif dan signifikan pada Komitmen organisasi memang terbukti benar. Semakin bagus kepemimpinan maka Organizational Commiment juga akan semakin bagus.

Hasil penelitian ini mendukung penelitian yang dilakukan Day dan Lord (2006) yang membuktikan bahwa kepemimpinan berperan besar dalam komitment organisasional di mana sasaran atau tujuan yang ingin dicapai adalah berupa 
kualitas layanan di suatu organisasi. Reksohardiprojo (2007) juga membuktikan bahwa kepemimpinan mempengaruhi banyak factor, salah satuya adalah kualitas layanan organisasional. Hasil penelitian ini pula dilakukan oleh May-Chiun Lo et al. (2009) yang menyatakan kepemimpinan berpengaruh positif terhadap komitmen organisasional dalam pelyanan jasa.

Hipostesis kedua dalam penelitian ini juga didukung, yaitu ada pengaruh signifikan motivasi terhadap Organizational Commitment. Makin tinggi movitasi maka semakin tinggi juga Organizational commitment. Motivasi untuk melaksanakan pekerjaan di layanan jasa akan berpengaruh pada organizational commitment. Hal ini sejalan dengan Daft (2003) juga membuktikan bahwa komitmen organisasional berpengaruh positif dan segnifikan terhadap organisasi layanan di rumah kesehatan.

Penelitian ini juga mendukung hipotesis 3 yang menyatakan adala pengaruh signifikan kepemimpinan terhadap kualitas layanan. Semakin bagus kepemimpinan, maka semakin bagus juga kualitas layanan rumah sakit. Hipotesis 4 yang menyatakan ada pengaruh signifikan Motivasi terhadap kualitas layanan juga diterima. Semakin tinggi motivasi, maka semakin baik juga kualitas layanan rumah sakit. Kepemimpinan berpengaruh posetif dan segnifikan terhadap kualitas layanan kesehatan di Rumah sakit. Hal ini sependapt dengan (Cholil, 2003) kepemimpinan berpengaruh posetif terhadap motivasi kerja karyawan di organisasi pelayanan jasa. 
Hasil analisis juga menunjukkan dukungan terhadap hipotesis 5 yaitu ada pengaruh signifikan Organizational commitment terhadap Kualitas layanan. Semakin tinggi Organizational Commitment, maka semakin tinggi juga kualitas layanan. Armanu (2004), dan Thoyib (2005) juga membuktikan bahwa komitmen organisasi berpengaruh positif terhadap services of quality dan memdapatkan justifikasi dukungan secara empirik sehingga hasil penelitian ini diaplikasikan pada persoalan-persoalan yang sama.

\section{SIMPULAN DAN SARAN}

\section{Simpulan}

Berdasarkan hasil penelitian diperoleh beberapa kesimpulan dalam penelitian ini, yaitu kepemimpinan berpengaruh positif signifikan terhadap komitmen di Rumah Sakit Referral Maubesi Kabupaten Ainaro. Pengaruh positif ini memberikan makna bahwa semakin baik penerapan kepemimpinan yang dilakukan maka semakin tinggi komitmen organisasional para karyawan Rumah Sakit Referral Maubessi Kabupaten Ainaro. Motivasi berpengaruh positif dan signifikan terhadap Komitmen organisasional. Hal ini mendapatkan justifikasi bahwa pengaruh positif ini dapat diartikan bahwa kepemimpinan mempunyai dampak positif terhadap Komitmen organisasional. Semakin baik penerapan kepemimpinan yang dilakukan maka semakin tinggi komitmen organisasional para karyawan. Kepemimpinan berpengaruh positif dan signifikan terhadap kualitas layanan. Pengaruh positif ini dapat diartikan bahwa semakin baik 
kepemimpinan yang dilakukan maka semakin meningkatkan kualitas layanan karyawan di Rumah Sakit Referral Maubessi.

Motivasi berpengaruh positif signifikan terhadap kualitas layanan di. Pengaruh positif ini dapat diartikan bahwa Motivasi menpuyai dampak positif terhadap kualitas layanan. Semakin baik Motivasi kerja karyawan maka semakin meningkat juga kualitas layanan karyawan di Rumah Sakit Referral Maubessi Kabupaten Ainaro.

\section{REFERENSI}

Armanu Thoyib, 2005,Hubungan Kepemimpinan, Budaya, Strategi, dan Kinerja: Pendekatan Konsep, Jurnal Manajemen \& Kewirausahaan,Vol. 7, No. 1, Maret 2005, h. 60- 73

Assauri, Sofjan 2006, Customer Service Yang Baik Landasan Pencapaian Customer

Chiun Lo et al. (2009) the impact of workplace empowerment, organizational trust on staff nurse 'work satisfaction and organizational commitment. Health Care Management Review Frederik, 3, 7-23.

Cholil, 2003. Assessing the Impact of Continuous Quality Improvement/Total Quality Management: Concept versus Implementation, Health Services Research 30, 2, 377-401.

Gomes, 2003, HIV Neuropathy: insight in the pathology of HIV peripheral nerve disease, J Peripher Nerv Syst, 6:21-7.

Hasibuan M. 2009. Manajemen Sumber Daya Manusia. Jakarta: Bumi Aksara

Jhon Kotter, P, 2010. Marketing Management. Analysis, Planning, Implementation, and Control, Prentice Hall International, Inc. Penerbit Mandar Maju, Bandung. P 49 
Kally E.M, 2004. Pengaruh Gaya Kepemimpinan adalah proses ketika seseorang atasan mendorong bawahannya untuk berprilaku sesuai keinginannya, mengarahkan dan mengoordinasi kerja anggota kelompok. Diunduh tanggal 29 September 2013. Dari http://www. repository.usu.ac.id

Koehler, 2010. "Interdisciplinary Foundations of Public Service Motivation.'In James L. Perry. Motivation in Public Management: The Call of Public Service. New York: Oxford University Press

Locke, and Latham, 2004. , Esensi Kepemimpinan (terjemahan), Mitra Utama, Jakarta.

Nursalam. 2009. Aplikasi dalam Praktik Keperawatan Profesional Edisi 2. Jakarta: Salemba Medika Organ \& Podsakoff 2006. Leadership style, organizational culture and performance: empirical evidence from United Kingdom Companies. Jurnal of Human resources Management. Vol 11, No. 4 pp 776-778

Porter dan Djati, eds. (2006 Handbook of British Chronology (3rd, reprinted 2003 Ed.). Cambridge: Cambridge University Press

Robbins, 2007, Perilaku Organisasi, Edisi kesepuluh, PT Indeks Jakarta.

Robbins, S.P. 2006. Organizational Behavior, Tenth Edition, Singapore: Prentice Hall.

Satisfaction, Jakarta: Usahawan No. 01 TH. XXXII, Januari, hal. 25-30.

Ridwan dan Kuncoro, 2008 Seperankat Variable exogen dan variable endogen Cetakan pertama Bandung; Alfabeta

Soeroso, S. 2005. Manajemen Sumber Daya Manusia di Rumah Sakit. Jakarta : ECG

Yukl, 2005, "Managerial Leadership: A Review of Theory and Research", Journal of Management, Vol 15, No.2, 251-289.

Zaithami, Valarei. A Mario Jo Bitner, 2004 Service Marketing: Integration Customer Focus across the fin, $3^{\text {rd }}$ ED, MC Graw Hill, New Work 